\title{
PROCES PIELĘGNOWANIA PACJENTA Z PRZEWLEKEYM ZAPALENIEM TRZUSTKI W UJĘCIU MIĘDZYNARODOWEJ KLASYFIKACJI PRAKTYKI PIELĘGNIARSKIEJ ICNP®
}

\author{
NURSING CARE OF A PATIENT WITH CHRONIC PANCREATITIS USING ICNP® \\ Paulina Landowska, Hanna Grabowska ${ }^{a}$
}

\author{
Pracownia Teorii i Podstaw Pielęgniarstwa, Instytut Pielęgniarstwa i Położnictwa, Wydział Nauk o Zdrowiu z Instytutem Medycyny Morskiej \\ i Tropikalnej, Gdański Uniwersytet Medyczny
}

${ }^{a}$ https://orcid.org/0000-0003-2999-7978

DOI: https://doi.org/10.20883/pielpol.2020.27

\section{STRESZCZENIE}

Wprowadzenie. Przewlekłe zapalenie trzustki (PZT) oznacza złożoną chorobę zapalną, charakteryzującą się postępującym niszczeniem tkanki gruczołowej, włóknieniem oraz zaburzeniami funkcji zewnątrz- i wewnątrzwydzielniczej.

Cel. Celem pracy jest przedstawienie procesu pielęgnowania pacjenta z przewlekłym zapaleniem trzustki z wykorzystaniem terminologii ICNP ${ }^{\circledR}$.

Opis przypadku. W pracy zastosowano metodę case study oraz technikę wywiadu, obserwacji, pomiarów i analizy dokumentacji medycznej pacjenta. W ocenie chorego wykorzystano skale C-HOBIC. Badanie przeprowadzono w Szpitalu im. M. Kopernika w Gdańsku na Oddziale Chorób Wewnętrznych i Diabetologii w maju 2019 r. i objęto nim 61-letniego pacjenta hospitalizowanego z powodu utrzymujących się dolegliwości bólowych jamy brzusznej, nudności, wymiotów oraz biegunki.

Wnioski. W wyniku przeprowadzonej oceny statusu pacjenta ogółem sformułowano 11 diagnoz pielęgniarskich, w tym 6 diagnoz aktualnych, odzwierciedlających status fizjologiczny chorego (ból brzucha [10043953], nudności [10012453], wymioty [10025981], biegunka [10000630], hiperglikemia [10027550] i zmienione ciśnienie krwi [10022954]), 1 diagnozę potencjalną (ryzyko infekcji [10015133]), a także 2 diagnozy dotyczące stylu życia chorego (nadużywanie alkoholu [10022234] i nadużywanie tytoniu [10022247]) oraz statusu psychologicznego (niepokój [10000477]) i samoopieki (brak wiedzy [10000837]).

W planie opieki pielęgniarskiej uwzględniono interwencje o charakterze diagnostycznym, związane z oceną i monitorowaniem statusu pacjenta, a także zarządzaniem stwierdzonymi u chorego symptomami oraz udziałem pielęgniarki w procesie terapeutycznym. Ważny element planu opieki stanowiły interwencje ukierunkowane na edukację zdrowotną oraz zapewnienie choremu komfortu psychicznego.

SŁOWA KLUCZOWE: przewlekłe zapalenie trzustki, proces pielęgnowania, klasyfikacja, ICNP.

\section{ABSTRACT}

Introduction. Chronic pancreatitis is a complex inflammatory disease characterized by progressive destruction of gland tissue, fibrosis, and disorders of exocrine and endocrine functions.

Aim. The aim of the study is to present the process of nursing care of patients with chronic pancreatitis using the ICNP® terminology.

Case study. The research employed the case study method and the technique of the interview, observation, analysis of medical records and measurements. The C-HOBIC data set was used to assess the patient's condition. The study was carried out at the Copernicus Hospital in Gdansk at the Department of Internal Medicine and Diabetes in May 2019 and included a 61-year-old patient hospitalized for persistent abdominal pain, nausea, vomiting and diarrhoea.

Conclusions. As a result of the assessment of the patient's condition, 11 nursing diagnoses were formulated, including 6 current diagnoses reflecting the patient's physiological status (abdominal pain [10043953], nausea [10012453], vomiting [10025981], diarrhoea [10000630], hyperglycaemia [10027550] and altered blood pressure [10022954]), 1 potential diagnosis (risk for infection [10015133]), as well as 2 diagnoses concerning the patient's lifestyle (alcohol abuse [10022234] and tobacco abuse [10022247]), psychological status (anxiety [10000477]) and self-care (lack of knowledge [10000837]).

The nursing care plan included diagnostic interventions related to the assessment and monitoring of the patient's status, as well as the management of symptoms and problems found in the patient, and the participation of the nurse in the therapeutic process. Interventions aimed at health education and providing mental comfort for the patient were an important part of the nursing care plan.

KEYWORDS: chronic pancreatitis, nursing process, classification, ICNP. 


\section{Wprowadzenie}

Przewlekłe zapalenie trzustki (PZT) oznacza złożoną chorobę zapalną, uwarunkowaną czynnikami idiopatycznymi, genetycznymi, toksyczno-metabolicznymi oraz środowiskowymi i autoimmunologicznymi. Charakteryzuje się postępującym niszczeniem tkanki gruczołowej, włóknieniem oraz zaburzeniami funkcji zewnątrzi wewnątrzwydzielniczej trzustki [1-3].

Szacuje się, że zapadalność na PZT w krajach wysoko rozwiniętych wynosi 4 przypadki na 100 tys. mieszkańców, natomiast w krajach skandynawskich jest ona dwukrotnie wyższa. W Polsce zachorowalność wynosi 8,5 na 100 tys. mieszkańców, przy czym dotyczy głównie osób w wieku 35-45 lat. Obserwuje się stały wzrost zachorowań, co spowodowane jest m.in. nadmiernym spożywaniem alkoholu, który odpowiada za 65-85\% przypadków PZT [2, 3].

W obrazie klinicznym PZT dominuje uczucie pełności oraz ból w nadbrzuszu, często promieniujący do pleców, nasilający się po spożyciu posiłku. Do objawów PZT należą wzdęcia, wymioty oraz spadek masy ciała. Charakterystyczne są również biegunki tłuszczowe oraz zaburzenia gospodarki węglowodanowej (cukrzycę stwierdza się u 10-35\% chorych). W przebiegu ciężkiej niewydolności zewnątrzwydzielniczej często dochodzi również do obniżenia stężenia w surowicy krwi witamin rozpuszczalnych w tłuszczach [2-4].

Priorytetem w leczeniu przewlekłego zapalenia trzustki jest przede wszystkim poprawa jakości życia pacjenta i redukcja ryzyka rozwoju powikłań. Leczenie pacjenta z PZT obejmuje podaż enzymów trzustkowych oraz preparatów przeciwbólowych, zaprzestanie picia alkoholu oraz palenia tytoniu, a także stosowanie diety (bogatokalorycznej, lekkostrawnej, bogatobiałkowej, o niskim indeksie glikemicznym, z suplementacją witamin). Pacjent powinien przyjmować 5-6 posiłków dziennie w odstępach 3-4 godzin. W sytuacji braku efektów leczenia zachowawczego włącza się metody zabiegowe (endoskopowe oraz operacyjne) [4-8].

Zatem w opiece pielęgniarskiej nad chorym z PZT skupić się należy przede wszystkim na kontroli bólu, rozwiązywaniu problemów związanych z zespołem złego wchłaniania oraz radzeniu sobie z przewlekłymi powikłaniami, takimi jak cukrzyca, wymagająca stosowania insulinoterapii [9-11].

Celem pracy jest przedstawienie procesu pielęgnowania pacjenta z przewlekłym zapaleniem trzustki z wykorzystaniem terminologii zawartej w Międzynarodowej Klasyfikacji Praktyki Pielęgniarskiej ICNP ${ }^{\circledR}$ (International Classification of Nursing Practice).

Słownik ICNP ${ }^{\circledR}$ należy do rodziny taksonomii Światowej Organizacji Zdrowia - wraz z ICD (Interna- tional Statistical Classification of Diseases and Related Health Problems) oraz ICF (International Classification of Functioning, Disability and Health). Został stworzony i jest rozwijany przez Międzynarodową Radę Pielęgniarek, a jego aktualizacja odbywa się co dwa lata (ostatnia wersja pochodzi z 2019 roku). Klasyfikacja ICNP® stanowi ujednolicony słownik terminów referencyjnych dla praktyki pielęgniarskiej, spełnia kryteria ISO (International Organization for Standards) i jest modelowana przy użyciu semantycznego języka sieci Web [12, 13]. Zawiera ponad cztery tysiące pojęć, w tym ponad osiemset diagnoz/wyników oraz ponad tysiąc interwencji pielęgniarskich, co w znaczący sposób ułatwia i przyspiesza dokumentowanie procesu pielęgnowania pacjentów (bez konieczności konstruowania z terminów wywodzących się z osi przedmiot i osąd - w odniesieniu do diagnoz oraz z osi działanie - w odniesieniu do interwencji). Każdy termin posiada odrębny, identyfikujący go kod, składający się z ośmiu cyfr. Stosowanie ICNP® zwiększa efektywność porozumiewania się pielęgniarek w różnych regionach świata i obszarach kulturowych $[14,15]$.

\section{Opis przypadku}

W pracy zastosowano metodę case study oraz technikę wywiadu, obserwacji, pomiarów i analizy dokumentacji medycznej pacjenta. W ocenie chorego wykorzystano skale C-HOBIC (Canadian Health Outcomes for Better Information and Care), wywodzące się z kanadyjskiego projektu, którego celem jest poprawa jakości opieki pielęgniarskiej. System C-HOBIC, zawiera liczne wskaźniki projakościowe i narzędzia oceny statusu funkcjonalnego (skale ADL i IADL), gotowości do wypisu/ samoopieki terapeutycznej, oceny symptomów (bólu, duszności, nudności, zmęczenia, kontynencji moczu) oraz bezpieczeństwa (ryzyka rozwoju odleżyn i ryzyka upadku) [16-18].

Badanie przeprowadzono w Szpitalu im. M. Kopernika w Gdańsku na Oddziale Chorób Wewnętrznych i Diabetologii w maju 2019 r., po uzyskaniu zgody dyrekcji szpitala, pielęgniarki oddziałowej, kierownika oddziału oraz chorego.

Pacjenta w wieku 61 lat przyjęto do szpitala z powodu utrzymujących się od 3 dni dolegliwości bólowych jamy brzusznej zlokalizowanych w okolicy środkowego śródbrzusza oraz podbrzusza. Chory zgłaszał również nudności i wymioty oraz luźne stolce. Pacjent przyznaje się do częstego spożywania alkoholu oraz do palenia papierosów (około 15 szt./ dobę). Rok wcześniej chory był hospitalizowany z powodu ostrego zapalenia trzustki, powikłanego torbielą rzekomą oraz podejrzenia perforacji przewodu Wirsunga, który zabezpieczono protezą. 
U pacjenta dokonano oceny funkcjonowania poszczególnych układów:

- oddechowego: bez zaburzeń, oddech miarowy, 17 oddechów/min;

- sercowo-naczyniowego: tętno - 80 ud/min, miarowe, dobrze napięte, pomiar na tętnicy promieniowej kończyny prawej; nadciśnienie tętnicze (158/86 mm Hg - po przyjęciu leków hipotensyjnych); saturacja $97 \%$;

- pokarmowego: nudności, wymioty, biegunka, masa ciała prawidłowa $\left(\mathrm{BMI}=23,43 \mathrm{~kg} / \mathrm{m}^{2}\right)$; jama ustna bez zmian;

- moczowo-płciowego: bez zaburzeń;

- nerwowego: pełna świadomość, kontakt słowno-logiczny zachowany, rytm snu i czuwania zachowany, zachowanie pacjenta adekwatne do sytuacji, pacjent niepokoi się o swój stan zdrowia, neguje omdlenia, zaburzenia równowagi oraz napady padaczkowe;

- narządów zmysłów: prawidłowe funkcjonowanie;

- $\quad$ kostno-stawowego: bez dolegliwości;

- $\quad$ powłok skórnych: skóra zadbana, bez uszkodzeń, ciepłota, napięcie, zabarwienie prawidłowe.

Podczas przyjęcia temperatura ciała wynosiła $36,3^{\circ} \mathrm{C}$. Stężenie glikemii we krwi włośniczkowej w kolejnych dniach hospitalizacji wahało się w zakresie: na czczo 107-135 mg\%; o godz. 12:00 - 143-164 mg\%; o godz. 16:00 - 97-125 mg\%; o 20:00 - 133-153 mg\%.

W wyniku oceny za pomocą skal C-HOBIC [18] u chorego stwierdzono w zakresie:

- $\quad$ statusu funkcjonalnego - chory zdolny do mobilności w łóżku, przemieszczania, chodzenia, ubierania, samodzielnego jedzenia, korzystania z toalety, wykonywania higieny;

- gotowości do wypisu/samoopieki terapeutycznej - częściowy deficyt wiedzy o reżimie leku i leczenia oraz świadomości objawów i zdolności zarządzania reżimem;

- $\quad$ oceny symptomów - ból utrzymujący się od kilku dni (intensywność bólu 7-8/10 pkt.; po podaniu leków przeciwbólowych - 3 pkt.), umiarkowane nudności. Duszności, zmęczenia oraz inkontynencji moczu nie stwierdzono;

- $\quad$ bezpieczeństwa - nie stwierdzono ryzyka rozwoju odleżyn i ryzyka upadku.

W badaniach laboratoryjnych stwierdzono wzrost stężenia lipazy (503 U/I), amylazy (216 U/I); ALT (63 U/I), AST (53 U/l) oraz glukozy (263 mg/dl) we krwi żylnej, a także stężenia amylazy (2795 U/I) w moczu. W badaniu USG jamy brzusznej stwierdzono powiększenie i stłuszczenie wątroby oraz obecność licznych zwap- nień trzustki w obrębie głowy o wielkości do $33 \mathrm{~mm}$. Trzon i ogon trzustki bez zmian, a w przewodzie Wirsunga była widoczna proteza. Ostatecznie u chorego zdiagnozowano zaostrzenie przewlekłego zapalenia trzustki o etiologii alkoholowej.

W leczeniu zastosowano leki przeciwbólowe, wprowadzono dożylną płynoterapię, leki z grupy inhibitorów pompy protonowej, inhibitorów konwertazy angiotensyny, kwas acetylosalicylowy, pankreatynę oraz doraźnie insulinę szybkodziałającą (w dawkach uzależnionych od wartości glikemii). Początkowo chory spożywał suchary oraz kleik, a następnie wprowadzono dietę trzustkową.

W planowaniu opieki pielęgniarskiej nad chorym zastosowano terminologię referencyjną $\operatorname{ICNP}^{\circledR}[14,19,20]$.

\section{Plan opieki pielęgniarskiej nad pacjentem z PZT}

\section{Diagnoza ICNP® 1. Ból brzucha [10043953]}

Interwencje ICNP®: monitorowanie bólu [10038929]; administrowanie lekiem przeciwbólowym [10023084]; zarządzanie bólem [10011660]; nauczanie o zarządzaniu bólem [10019489]; identyfikowanie postawy wobec bólu [10009654]; ewaluacja odpowiedzi na zarządzanie bólem [10034053].

Wynik ICNP®: Zredukowany ból [10027917]

\section{Diagnoza ICNP® 2. Nudności [10012453]}

Interwencje ICNP®: ocenianie nudności [10043694]; nauczanie o zarządzaniu nudnościami [10043687]; zarządzanie nudnościami [10043673]; zachęcanie do odpoczynku [10041415]; zapewnienie prywatności [10026399]; zastosowanie urządzenia zabezpieczającego [10002472]; pozycjonowanie pacjenta [10014761].

Wynik ICNP®: Bez nudności [10028984]

\section{Diagnoza ICNP® 3. Wymioty [10025981]}

Interwencje ICNP®: zarządzanie wymiotami [10046329]; pozycjonowanie pacjenta [10014761]; asystowanie w czynnościach toaletowych [10023531]; zapewnienie prywatności [10026399]; zastosowanie urządzenia zabezpieczającego [10002472]; zarządzanie reżimem diety [10023861]; nauczanie o pielęgnacji jamy ustnej [10023531]. Wynik ICNP®: Bez wymiotów [10029181]

\section{Diagnoza ICNP® 4. Biegunka [10000630]}

Interwencje ICNP®: ocenianie biegunki [10043656]; ocenianie kału [10050172]; zarządzanie biegunką [10043641]; nauczanie o zarządzaniu biegunką [10043660]; zapewnienie prywatności [10026399]; promowanie higieny [10032477]; współdziałanie w terapii płynami [10030948]. Wynik ICNP®: Bez biegunki [10040063] 


\section{Diagnoza ICNP® 5. Hiperglikemia [10027550]}

Interwencje ICNP®: monitorowanie stężenia glukozy we krwi [10032034]; zarządzanie poziomem glukozy we krwi [10046262]; administrowanie insuliną [10030417]. Wynik ICNP®: Hiperglikemia [10027550]

\section{Diagnoza ICNP® 6. Niepokój [10000477]}

Interwencje ICNP ${ }^{\circledR}$ : ocenianie niepokoju [10041745]; zarządzanie niepokojem [10031711]; informowanie o hospitalizacji [10042480]; zapewnienie wsparcia emocjonalnego [10027051]; wspieranie statusu psychologicznego [10019161].

Wynik ICNP®: Zredukowany niepokój [10027858]

\section{Diagnoza ICNP® 7. Zmienione ciśnienie krwi [10022954]} Interwencje ICNP®: monitorowanie ciśnienia krwi [10032052]; administrowanie lekiem [10025444]. Wynik ICNP®: Zmienione ciśnienie krwi [10022954]

\section{Diagnoza ICNP® 8. Nadużywanie alkoholu [10022234]} Interwencje ICNP®: ocenianie nadużycia alkoholu [10044107]; poradnictwo dotyczące alkoholu [10031036]; nauczanie o nadużywaniu alkoholu [10044900]; ułatwienie regeneracji po nadużywaniu alkoholu [10035856]. Wynik ICNP®: Bez nadużywania alkoholu [10028765]

\section{Diagnoza ICNP® 9. Nadużywanie tytoniu [10022247]} Interwencje ICNP®: ocenianie używania tytoniu [10038606]; ocenianie gotowości do rzucenia palenia [10038623]; poradnictwo dotyczące stosowania tytoniu [10031058]; nauczanie o rzuceniu palenia [10038647]. Wynik ICNP®: Bez nadużywania tytoniu [10029147]

\section{Diagnoza ICNP® 10. Brak wiedzy [10000837]}

Interwencje ICNP ${ }^{\circledR}$ : ocenianie wiedzy [10033882]; nauczanie o potrzebach dietetycznych [10046533]; nauczanie oodżywianiu[10024618]; nauczanie ochorobie[10024116]; nauczanie o nadużywaniu substancji [10024639]; nauczanie o pomiarze ciśnienia krwi [10044148]; nauczanie o zachowaniach prozdrowotnych [10032956]; nauczanie o kontrolowaniu objawów podmiotowych [10038080]; zapewnienie materiału instruktażowego [10024493]. Wynik ICNP®: Adekwatna wiedza [10027112]

\section{Diagnoza ICNP® 11. Ryzyko infekcji [10015133]} Interwencje ICNP®: ocenianie podatności na infekcję [10002821]; ocenianie oznak i symptomów infekcji [10044182]; utrzymywanie drożności dostępu dożylnego [10036577]; używanie techniki aseptycznej [10041784]. Wynik ICNP®: Bez infekcji [10028945]

\section{Dyskusja}

Opiekując się pacjentem z przewlekłym zapaleniem trzustki pielęgniarka powinna dokonać bardzo wnikliwej i rzetelnej oceny jego funkcjonowania we wszystkich aspektach życia, co umożliwi sformułowanie właściwego planu opieki. W procesie pielęgnowania należy zidentyfikować również posiadane przez chorego zasoby, aby wdrożyć optymalny zakres interwencji, zapewniający osiągnięcie oczekiwanych wyników oraz satysfakcję pacjenta [9-11].

Za kluczowe w diagnozie pielęgniarskiej dla pacjentów z PZT uznano: uporczywe biegunki będące wynikiem upośledzonego trawienia pokarmów [10], brak wiedzy na temat diety w przewlekłym zapaleniu trzustki [10], trudności w podejmowaniu aktywności życia codziennego z powodu utrzymujących się dolegliwości bólowych/deficyt samoopieki [11], osłabienie wynikające z wyniszczenia organizmu [11] oraz możliwość nawracających epizodów zaostrzenia zapalenia trzustki z powodu nadużywania alkoholu i palenia papierosów [11]. Większość z nich stwierdzono również u opisanego w niniejszej pracy chorego. W wyniku przeprowadzonej oceny statusu pacjenta ogółem sformułowano 11 diagnoz pielęgniarskich, w tym 6 diagnoz aktualnych, odzwierciedlających status fizjologiczny chorego (ból brzucha [10043953], nudności [10012453], wymioty [10025981], biegunka [10000630], hiperglikemia [10027550] i zmienione ciśnienie krwi [10022954]), 1 diagnozę potencjalną (ryzyko infekcji [10015133]), a także 2 diagnozy dotyczące stylu życia chorego (nadużywanie alkoholu [10022234] i nadużywanie tytoniu [10022247]) oraz statusu psychologicznego (niepokój [10000477]) i samoopieki (brak wiedzy [10000837]).

W piśmiennictwie podkreśla się znaczenie odpowiedniego przygotowania chorych z przewlekłym zapaleniem trzustki do wypisu ze szpitala. Barierę w osiągnięciu założonych celów opieki może stanowić przewlekły charakter schorzenia, a także konieczność stosowania skomplikowanych schematów leczenia w domu oraz podjęcia interwencji psychospołecznych $[9,21]$, stąd potrzeba zastosowania w procesie pielęgnowania podejścia zindywidualizowanego i holistycznego oraz edukacji zdrowotnej zarówno samego chorego, jak i jego bliskich.

Przedstawione choremu - zgodnie z zaleceniami zawartymi w przytoczonym w niniejszej pracy piśmiennictwem - potencjalne korzyści wynikające ze stosowania zaleceń dietetycznych oraz zaniechania palenia tytoniu i spożycia alkoholu, wzmocniły jego motywację i deklarację wdrożenia pożądanych w przebiegu PZT zachowań zdrowotnych.

W efekcie podjętych interwencji uzyskano redukcję zgłaszanego przez chorego niepokoju, zmniejszenie natężenia odczuwanego przez pacjenta bólu, ustąpienie nudności, wymiotów oraz biegunki. 


\section{Wnioski}

1. W opiece nad chorym z PZT uwzględniono interwencje o charakterze diagnostycznym, związane z oceną i monitorowaniem statusu pacjenta, a także zarządzaniem stwierdzonymi u chorego zaburzeniami oraz udziałem pielęgniarki w procesie terapeutycznym. Ważny element opieki nad chorym stanowiły interwencje ukierunkowane na edukację zdrowotną oraz zapewnienie choremu komfortu psychicznego.

2. Zastosowana $\mathrm{w}$ pracy terminologia $\mathrm{ICNP}^{\circledR}$ umożliwiła skonstruowanie przejrzystego planu opieki pielęgniarskiej nad pacjentem z przewlekłym zapaleniem trzustki.

\section{Piśmiennictwo}

1. Pham A, Forsmark C. Chronic pancreatitis: review and update of etiology, risk factors, and management. F1000Research (F1000 Faculty Rev) 2018; 7(607): 1-11.

2. Dąbrowski A, Jurkowska G, Wereszczyńska-Siemiątkowska U. Choroby trzustki. W: Gajewski P. Interna Szczeklika. Kraków: Medycyna Praktyczna; 2016. 1064-1091.

3. Kadaj-Lipka R, Lipiński M, Adrych K i wsp. Zalecenia diagnostyczne i terapeutyczne w przewlekłym zapaleniu trzustki. Rekomendacje Grupy Roboczej Polskiego Towarzystwa Gastroenterologii oraz Polskiego Klubu Trzustkowego. Prz Gastroenterol. 2018; 13(3): 167-181.

4. Szczepanek M, Goncerz G, Dąbrowski A, Sierżęga M. Rozpoznawanie i leczenie przewlekłego zapalenia trzustki. Omówienie wytycznych europejskich (HaPanEu) 2016. Med Prakt. 2018; 1: 30-55.

5. D'Haese J, Ceyhan G, Demir I et al. Treatment options in painful chronic pancreatitis: a systematic review. HPB 2014; 16: 512-521.

6. Siepsiak M, Adrych K. Leczenie zachowawcze, endoskopowe i chirurgiczne chorych na przewlekłe zapalenie trzustki. Farmacja Współ. 2014; 7: 169-174.

7. Dominguez-Munoz E, Rosendahl J, Besseling M et al. United European Gastroenterology evidence-based guidelines for the diagnosis and therapy of chronic pancreatitis. United European Gastroenterol J. 2016; 5(2): 1-47.

8. Włochal M, Grzymisławski M. Rola żywienia w leczeniu przewlekłego zapalenia trzustki. Piel Zdr Publ. 2013; 3(3): 303-310.

9. Johnstone CC. An overview of the management of patients with chronic pancreatitis. Nurs Stand. 2016; 31(13): 54-63.

10. Jarocka I, Perkowska U. Opieka pielęgniarska nad pacjentem z chorobami trzustki. W: Jurkowska G, Łagoda K (red.). Pielęgniarstwo internistyczne. Podręcznik dla studiów medycznych. Warszawa: Wydawnictwo Lekarskie PZWL; 2015. 227-240.

11. Talarska D, Strugała M. Opieka pielęgniarska nad osobami z chorobami układu pokarmowego. W: Talarska D, Zozulińska-Ziółkiewicz D (red.). Pielęgniarstwo internistyczne. Warszawa: Wydawnictwo Lekarskie PZWL; 2017. 184-188.
12. Kilańska D. Terminologia referencyjna i jej znaczenie dla praktyki. W: Kilańska D, Grabowska H, Gaworska-Krzemińska A (red.). E-zdrowie. Wprowadzenie do informatyki w pielęgniarstwie. Warszawa: Wydawnictwo Lekarskie PZWL; 2018. 347-362.

13. Bartz CC, Kim TY, Kilańska DM. Standard terminology for nursing. Probl. Pielęg. 2017; 25(2): 108-111.

14. International Council of Nurses. International Classification for Nursing Practice (ICNP®). ICNP® Browser. https:// www.icn.ch/what-we-do/projects/ehealth/icnp-browser [dostęp 27.05.2019 r.].

15. Grabowska H, Kilańska D, Gaworska-Krzemińska A. Metoda pracy pielęgniarki w praktyce klinicznej. Proces pielęgnowania i zastosowanie terminologii referencyjnej. W: Kilańska D, Grabowska H, Gaworska-Krzemińska A (red.). E-zdrowie. Wprowadzenie do informatyki w pielęgniarstwie. Warszawa: Wydawnictwo Lekarskie PZWL; 2018. 367-396.

16. Hannah K, White PA, Kennedy MA. C-HOBIC - Standardized Information to Support Clinical Practice and Quality Patient Care across Canada. Nurs Inform. 2012: 142.

17. Canadian Health Outcomes for Better Information and Care Project [https://c-hobic.cna-aiic.ca/about/default_e.aspx dostęp 27.05.2019].

18. Andruszkiewicz A. Studium przypadku HOBIC. W: Kilańska D, Grabowska H, Gaworska-Krzemińska A (red.). E-zdrowie. Wprowadzenie do informatyki w pielęgniarstwie. Warszawa: Wydawnictwo Lekarskie PZWL; 2018. 236-265.

19. Grabowska H, Grabowski W, Gaworska-Krzemińska A. Mapowanie fraz opisujących diagnozy i interwencje pielęgniarskie w opiece nad chorym z cukrzycą z wykorzystaniem ICNP®. Pielęg XXI w. 2014; 3(48): 37-42.

20. Grabowska H, Grabowski W, Gaworska-Krzemińska A. Wykorzystanie ICNP® w opiece pielęgniarskiej nad pacjentem z nadciśnieniem tętniczym. Probl Pielęg. 2014; 22(1): 107-112.

21. Smith SB. Discharge planning for the patient with chronic pancreatitis. Gastroenterol Nurs. 2013; 36(6): 415-9.

Artykuł przyjęty do redakcji: 19.11.2019.

Artykuł przyjęty do publikacji: 13.05.2020.

Źródło finansowania: Praca nie jest finansowana z żadnego źródła. Konflikt interesów: Autorzy deklarują brak konfliktu interesów.

Adres do korespondencji:
Hanna Grabowska
ul. Dębinki 7/15
80-211 Gdańsk
tel.: 0/58 3491980
e-mail: hanna.grabowska@gumed.edu.pl
Pracownia Teorii i Podstaw Pielęgniarstwa, Instytut Pielęgniarstwa
i Położnictwa, Wydział Nauk o Zdrowiu z Instytutem Medycyny
Morskiej i Tropikalnej, Gdański Uniwersytet Medyczny

Adres do korespondencji:

Hanna Grabowska

ul. Dębinki 7/15

80-211 Gdańsk

tel.: 0/58 3491980

e-mail: hanna.grabowska@gumed.edu.pl

Pracownia Teorii i Podstaw Pielęgniarstwa, Instytut Pielęgniarstwa

Morskiej i Tropikalnej, Gdański Uniwersytet Medyczny 